\title{
Dukan Dam Reservoir Bed Sediment, Kurdistan Region, Iraq
}

\author{
Rebwar Hassan', Nadhir Al-Ansari'1, Salahalddin S. Ali' ${ }^{2}$, Ammar A. Ali' ${ }^{1}$, Twana Abdullah1, \\ Sven Knutsson 1 \\ ${ }^{1}$ Luleå University of Technology, Lulea, Sweden \\ ${ }^{2}$ Department of Geology, University of Sulaimani, Sulaymaniyah, Iraq \\ Email: rebwar.hassan@ltu.se, Nadhir.alansari@ltu.se,ammar.ali@ltu.se, salahalddin.ali@univsul.edu.iq, twana.abdullah@ltu.se, \\ Sven.Knutsson@ltu.se
}

How to cite this paper: Hassan, R., AlAnsari, N., Ali, S.S., Ali, A.A., Abdullah, T. and Knutsson, S. (2016) Dukan Dam Reservoir Bed Sediment, Kurdistan Region, Iraq. Engineering, 8, 582-596.

http://dx.doi.org/10.4236/eng.2016.89054

Received: July 22, 2016

Accepted: September 9, 2016

Published: September 13, 2016

Copyright $\odot 2016$ by authors and Scientific Research Publishing Inc. This work is licensed under the Creative Commons Attribution International License (CC BY 4.0).

http://creativecommons.org/licenses/by/4.0/

\begin{abstract}
The Dukan Dam Reservoir (DDR) in the Kurdistan Region of Iraq has been studied to determine the characteristics and nature of the reservoir and the deposited sediments on its bottom surface. This study was achieved by doing a field survey and grain size analyses of the collected sediment samples at 32 locations representing the whole reservoir area that had been created when the Lesser Zab River was dammed in 1959. The Dukan Dam, which is a multi-purpose concrete arch dam, was built on the Lesser Zab River for controlling its flood during high rainfall seasons, irrigation and power generation. The catchment area is $11,690 \mathrm{~km}^{2}$. The surface area of the reservoir is 270 square kilometers and the volume is $6.870 \times 106 \mathrm{~m}^{3}$ at normal operation level (El. $511.00 \mathrm{~m}$. a.s.l.). The minimum drawdown level is at elevation $469 \mathrm{~m}$ above sea level (a.s.l.). The live storage is $6.14 \times 106 \mathrm{~m}^{3}$ while the remainder is dead storage. The reservoir has a surface area that reaches 270 square kilometers and is composed of two sub-reservoirs connected by a narrow channel that has a length of 5 kilometers. The relatively bigger reservoir is located in the north and has a triangular shape with a surface area approximately 250 square kilometers. The smaller sub-reservoir is located down south where the dam exists and it has irregular rectangular shape. Thirty-two sediment samples were collected from the bottom of Dukan reservoir. The bed of the reservoir is mainly composed of $15 \%$ gravel, $14 \%$ sand, $48 \%$ silt and 23\% clay respectively. Most of the sediments are very fine grained, very poorly sorted, strongly coarse skewed and mesokurtic.
\end{abstract}

\section{Keywords}

Sediment, Dukan Reservoir, Iraq 


\section{Introduction}

In nature, most of the unconstrained rivers by dams are in an equilibrium state, which means that the sediment inflow and outflow are balanced. This balance is changed with time in dammed rivers because dams trap both water and sediment which cause increasing flow depth velocity (settling capacity) and decreasing flow velocity (transporting capacity) and finally lead to the deposition of the carried sediment by rivers in the reservoirs [1].

Sedimentation is a natural complex process that consists of erosion, transportation and deposition [2]. Rivers have sufficient energy to do headward, lateral and vertical erosion of the banks and the ground surfaces over the flow by hydraulic action, corrasion and corrosion processes. The eroded rocks are broken into smaller fragments by attrition process. The river sediments become smaller and more rounded towards the rivers downstream. Rivers transport the large-sized eroded materials such as boulders by pushing and rolling processes (traction), whilst the relatively smaller sized particles are transported by saltation process. The fine materials like silt and clay are lifted in rivers by the turbulence and transported as suspended load to further distances. The dissolved materials are transported by the solution load process. The energy loss of the rivers causes sinking and settling down of the carried sediments by the rivers. Sedimentation, in the reservoirs, is dependent on the nature of the rivers, geometry of the reservoirs and the dams operation. The dams cause slowing down flow velocity of the dammed rivers which feed the reservoirs and therefore reduce the rivers ability to transport the carried sediments which begin to settle down on the bottom of the reservoirs. The coarser sediments (pebbles and gravels) will be deposit first far away from the dam near to its upstream end forming a backwater delta that moves towards the dam body with time, whilst the finer suspended materials (silt and clay) deposit near to the dam body, in addition to passing the very finest colloidal particles through the outlet of the dam (Figure 1). The topset, foreset and bottomset deposits at the bottom of dam reservoirs represent roughly $(\approx 95 \%)$ the total sediments which enter dam reservoirs and the remained $5 \%$ of the entered sediments (fine particles) go out to the front of the dam body as reservoir outflow (Figure 1).

The process by which the reservoirs get silts and clays with time is known as siltation. Siltation has negative effects on the future of the dams and reservoirs because it brings reduction in storage capacity of the reservoir, water pollution due to the increased concentration of suspended sediments and damages to the dam and power generating turbines. Reservoir sedimentation will decrease annually by about 0.5 to $1 \%$ of the total storage capacity [3] [4]. In order to let the dams be far away from collapses and the whole dam structures be also protected from damages, the dam designers and operators have put the importance of the sedimentation management in their considerations.

Continuous and increased accumulation of fine sediments on the bottom of Dukan Dam Reservoir (over 56 years of sedimentation) is a big and dangerous problem which the technicians who are working in the Dukan Dam might be facing. Protection of Dukan Reservoir Dam from the risks of siltation phenomenon encouraged the researchers to 


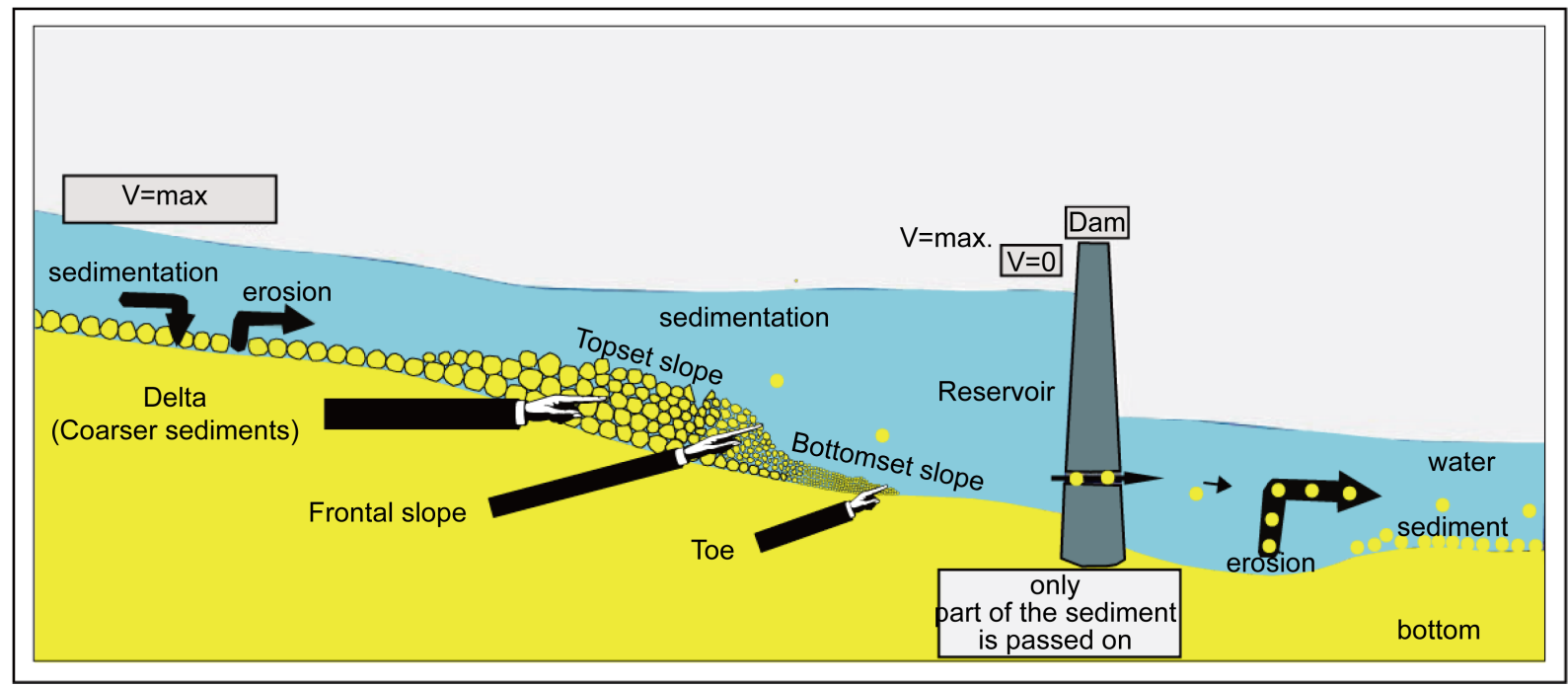

Figure 1. Schematic diagram shows the deposition of the carried sediments in the reservoirs.

think about doing a scientific research on the nature and distribution of the deposited sediments on the bottom of the Dukan Dam Reservoir that is to elongate its operating age, avoiding the Region from an environmental catastrophe, i.e., dam failure, water scarcity and water pollution, too. To achieve this goal, it has been mainly dependent on grain size analysis and its statistical parameters because they are useful tools for more understanding the sedimentary environments, transport history and depositional conditions [5]-[8].

\section{Dukan Dam Reservoir}

The Dukan Dam Reservoir (DDR) that has been created due to the construction of Dukan Dam on the Lesser Zab River in 1954 separates the Greater Zab Basin in the north from the Sirwan River Basin in the south (Figure 2(a)). Geographically, the study area (Dukan Dam Reservoir) is located between the longitudes $\left(44^{\circ} 48^{\prime} 00^{\prime \prime} \mathrm{E}\right)$ and $\left(45^{\circ} 03^{\prime} 00^{\prime \prime} \mathrm{E}\right)$ and the latitudes from $\left(35^{\circ} 56^{\prime} 00^{\prime \prime} \mathrm{N}\right)$ to $\left(36^{\circ} 15^{\prime} 00^{\prime \prime} \mathrm{N}\right)$, covering about 900 $\mathrm{km}^{2}$ in northwest of Sulaimani city in Kurdistan Region-NE Iraq (Figure 2(b)). The Dukan Dam Reservoir (DDR) is a natural depression that locates in a plane extending between the Darbandi Rania (Kewa-Rash Mountains) and the dam itself (Figure 2(b)). A narrow steep sided channel divides the DDR into two sub-reservoirs; the bigger triangle-shaped sub-reservoir that represents the majority of the reservoir at the north of the reservoir, and the smaller irregular-shaped sub-reservoir locating at the south of the reservoir (Figure $2(\mathrm{~b})$ ). The reservoir has a surface area that reaches 270 square kilometers composed of two sub-reservoirs. The relatively bigger reservoir is located in the north and has a triangular shape with a surface area approximately 250 square kilometers. The smaller sub reservoir is located down south where the dam exists and it has irregular rectangular shape (Figure $2(\mathrm{~b})$ ). The two sub reservoirs are connected by a channel which is about 5 kilometers long.

The Dukan Dam itself is located at the coordinates ( $\left.35^{\circ} 57^{\prime} 15^{\prime \prime}\right) \mathrm{N} \&\left(44^{\circ} 57^{\prime} 10^{\prime \prime}\right) \mathrm{E}$, 


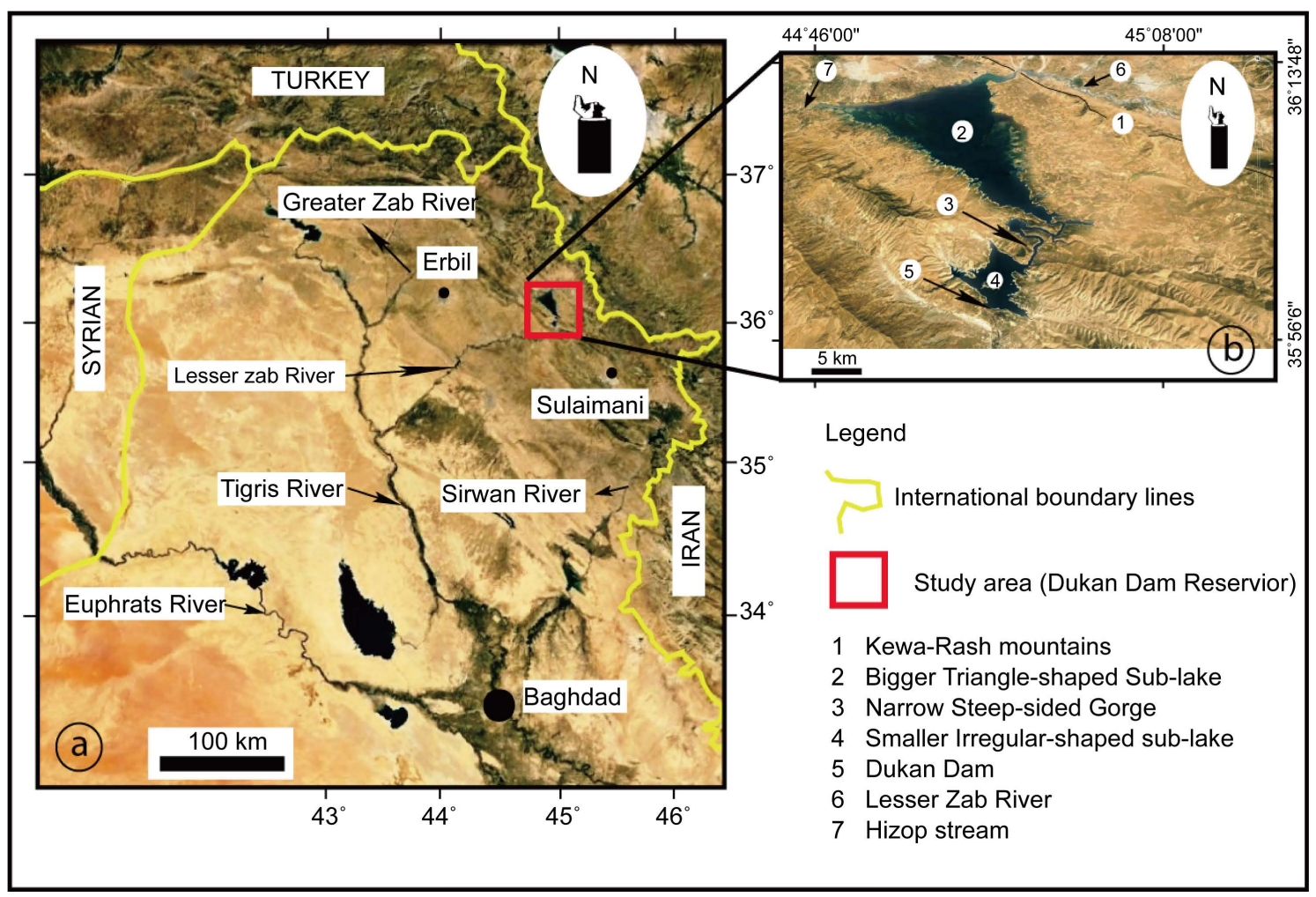

Figure 2. Location map of the Dukan Dam Reservoir. (a) Iraq map shows the main rivers in Iraq the location of the Dukan Reservoir Dam. (b) A photo taken from Google earth showing the geographic location, the main rivers feeding the reservoir and its division into two sub-reservoirs (Google earth).

about $(60 \mathrm{~km})$ NW of Sulaimani city. The Dukan Dam, which is a multi-purpose concrete arch dam, was built on the Lesser Zab River for controlling its flood during high rainfall seasons. The dimensions of the dam are $(360 \mathrm{~m}$ long $\times 116.5 \mathrm{~m}$ high; width 6.2 $\mathrm{m}$ and $34.3 \mathrm{~m}$ at crest and base) [9]. It is one of the oldest dams in Iraq where it was operating in 1959. It is the most strategic engineering projects in Kurdistan Region/NE Iraq because it is a main fresh water storage (total capacity $=6.970 \times 106 \mathrm{~m}^{3}$ ) that provides the Region with water needed for domestic, agricultural and industrial uses, besides supplying the electricity grid of the Region with enough power (maximum capacity $=400 \mathrm{MV}$ ).

The Lesser Zab River is a main source for providing the DDR with water. It is originated from the junction of two small streams to form the Chami Kalvem in the Azarbayjani Gharbi region in Iran that flows in a south-southeasterly direction and enters Iraqi Kurdistan Region then near Mawat town. Inside Kurdistan Region, near Penjwin town, it joins with the Siwayl River and flows then in a northwesterly direction towards Rania town until it enters the DDR. Hizop Stream that flows southeasterly is a secondary source for providing DDR with water. Both the Lesser Zab River and Hizopstrean are fed by rainfall and snowmelt. The Lesser Zab River enters the Tigris River north of Bayji town. The total catchment area of the Lesser Zab River is $22,250 \mathrm{~km}^{2}$. Geologically, the DDR locates in the High Zagros Fold-Thrust Zone [10] (Figure 3). The Qam- 

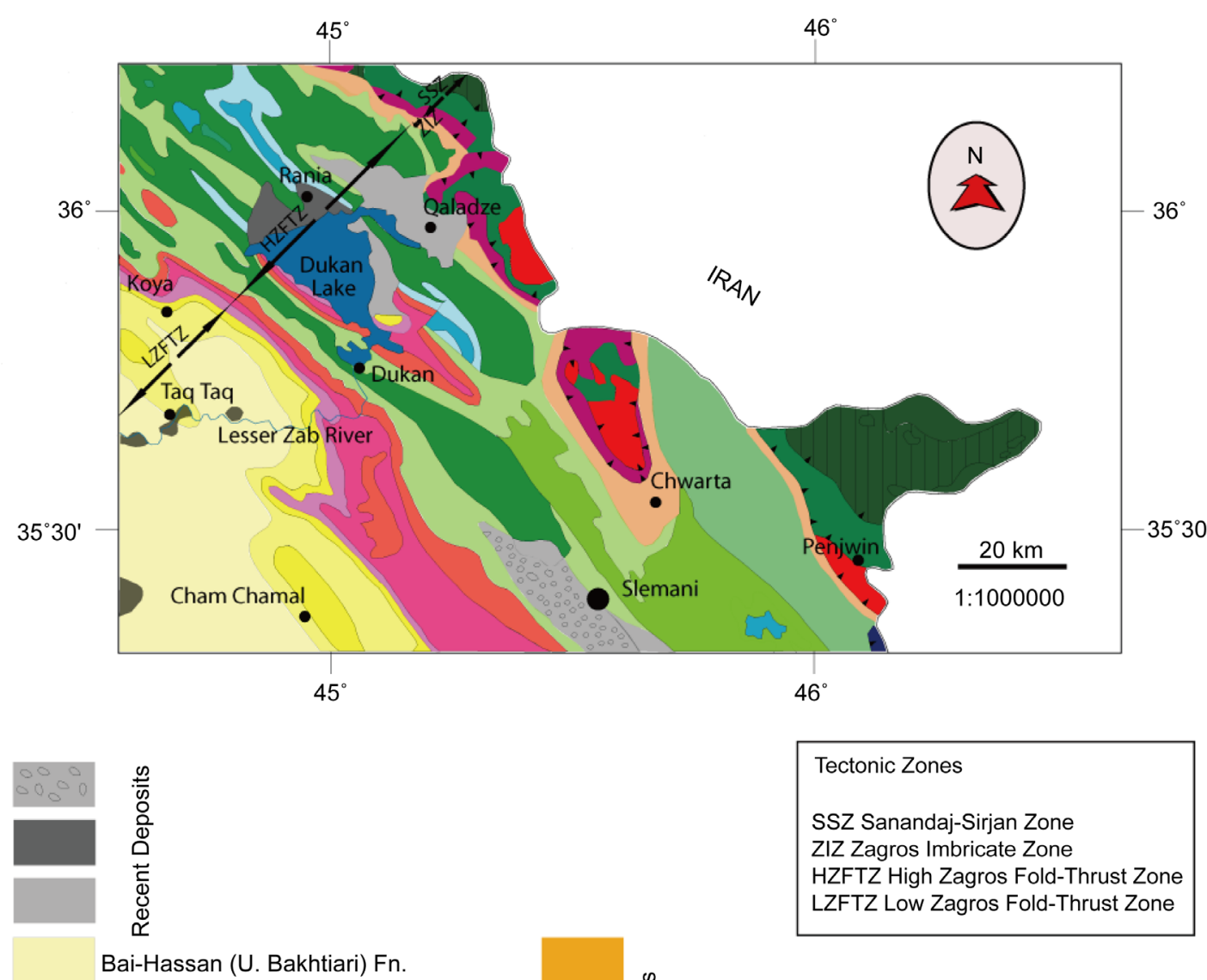

Mukdadia (L. Bakhtiari) Fn.

Injana (U.Fars) Fn.

Fatha (L.Fars) Fn.

Gercus, Pila Sipi Fns.

Kolosh, Sinjar Fns.

Shiranish, Tanjero Fns.

Qamchuqa Fn.

Balambo, Kometan, Dukan, Gulneri Fns.

Middle, upper Jurassic Fns.
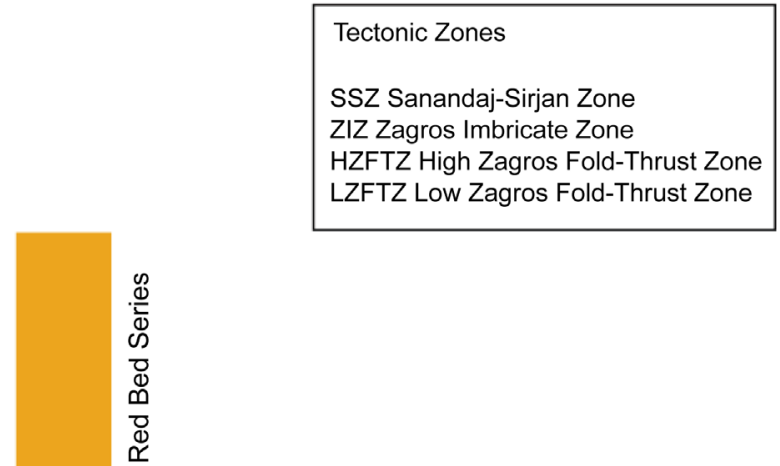

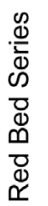

Lower Jurassic Fns.

Avroman Limestone

Figure 3. A geological map showing the surface distribution of the Stratigraphic Units in the study area [15].

chuqa, Kometan, Shiranish, Tanjero, Kolosh and Sinjar formations with recent alluvial deposits are exposed on the surface (Figure 3). The major anticlines are NW-SE trending doubly plunging, asymmetrical and verging towards southwest. They appear as a 
broad box like geometry separated by narrow deep anticlines in between [11] [12]. The cores of these major anticlines are composed of the Mesozoic limestone units where, the Palaeogene and Neogene limestone and clastics are seen on their flanks [13]. Dukan Dam was constructed on the Lesser Zab River where it crosses the axis of asymmetrical doubly plunging Sara anticline through a gorge or a transversal narrow valley. The core of Sara Anticline consists of the dolomitic and calcareous units of the Qamchuqa and Kometan formations (marls, limestone's and dolomites) where the Shiranish, Tanjero formations are seen on the limb across the strike direction [14] (Figure 4).

\section{Methodology}

Thirty-two locations have been selected for taking the samples of the deposited sediments at the bottom surface of the Dukan Dam Reservoir (Figure 5). A Van Veen Grab sampler was used for collecting these sediment samples because it is an easily used instrument for sampling sediments in water environments (Figure 6(a)). The absolute $x$, $\mathrm{y}, \mathrm{z}$ coordinates of the sample locations were determined by using Echo Sounder Sea Charter 480DF (Figure 6(b)). The procedure of how the samples were taken at the bottom of the reservoir was shown in (Figure 6(c)).

Sieve and hydrometer analyses were done for the collected sediment samples in both the Andria Technical Lab in Erbil governorate and the soil mechanic lab of the college of engineer/Sulaimani University in Sulaimani governorate (Figure 7). The graphical and statistical methods were utilized to classify and compare the sediments simply and rapidly. In the graphical technique, which is known, as (Folk classification), the sand, silt and clay percentages on an equilateral triangular diagram is used [16] [17].

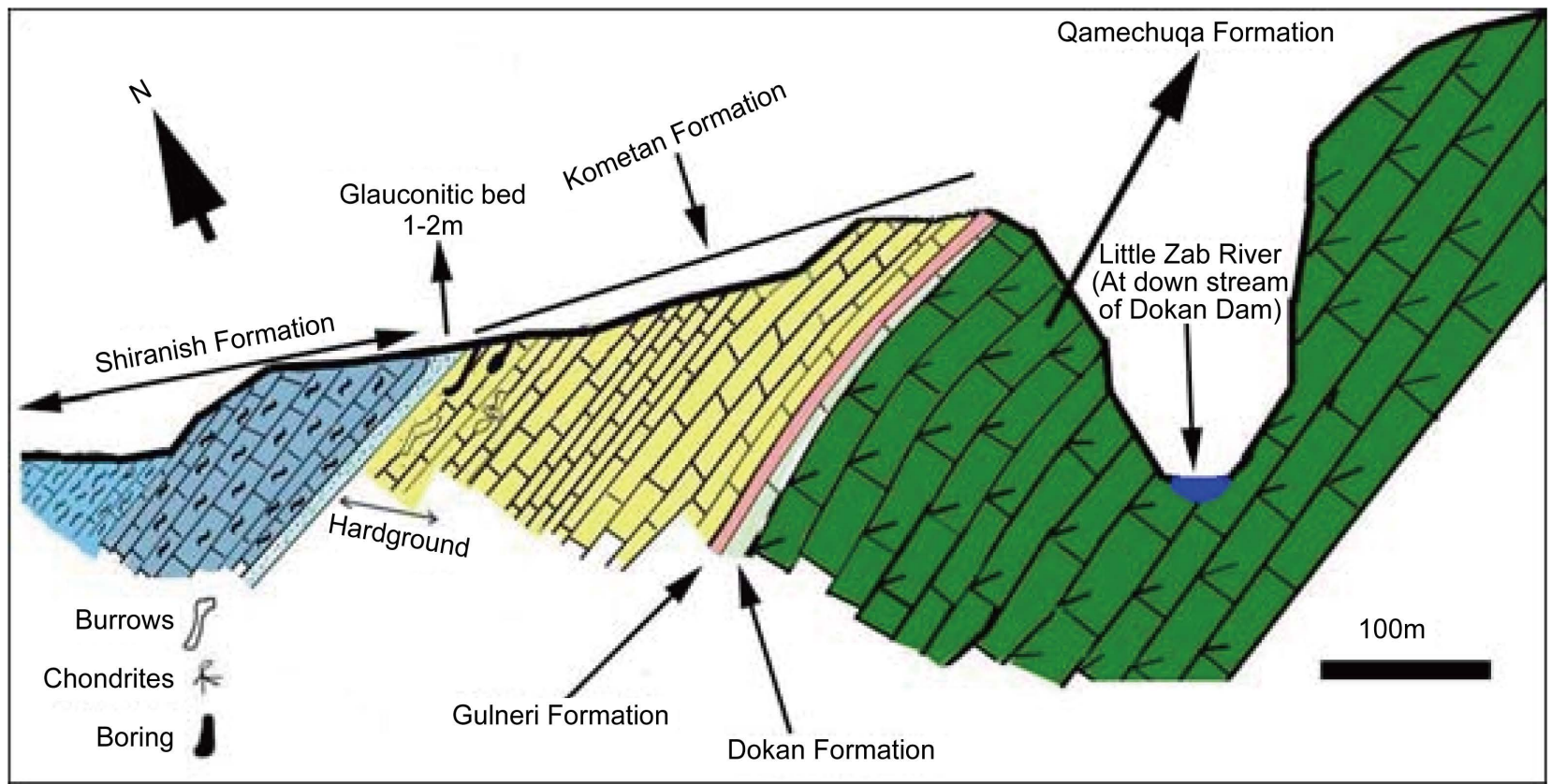

Figure 4. A schematic geologic cross section across the gorge directly to the south of the dam site [16]. 


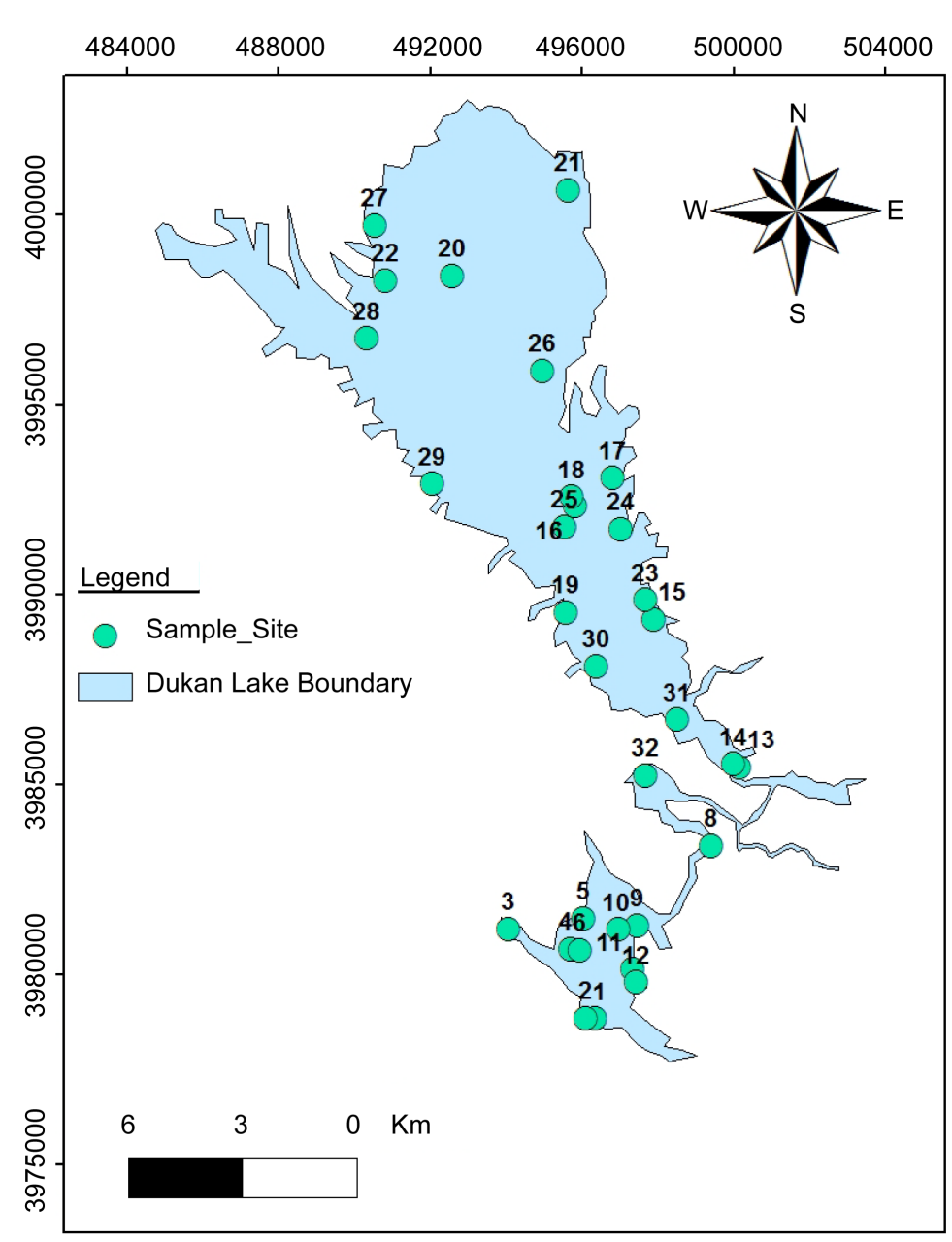

Figure 5. A map shows the location of the samples taken at the bottom of the Dukan Dam Reservoir.

\section{Results and Discussion}

Grain size analysis is a useful tool for more understanding the sediment provenance, transport history and the depositional environments. Generally, the bed of the reservoir is mainly composed of 15\%:14\%:48\%:23\% gravel, sand, silt and clay respectively. The surface area of the bottom of the reservoir is covered by (89.9\%), (6\%), (3\%) and (1.2\%) of clay, sandy silt, gravel and sand sediments respectively (Figure 8 ). The clay sediments are composed of silty clay $(77.6 \%)$, silty sandy clay $(10 \%)$, sandy gravely silty clay (1.2\%) and gravely sandy silty clay (1\%). The gravel sediments (sandy silty clayey gravel and sandy gravel) are deposited at the shore lines of the bigger and smaller sub-reservoirs and this may be due to the wave actions (Figure 9(a)). The gravely silty clayey sand and gravely sand are mostly deposited in the smaller irregular-shaped sub-reservoir and as small patches at the east and west shore lines of the lower part of the bigger triangle- shaped sub-reservoir (Figure 9 (b)). More than $75 \%$ of the sandy silt sediments are deposited near to the entrance of the Lesser Zab river into the bigger sub-reservoir, whilst, the rest of the bigger sub-reservoir and near to the dam site in the 


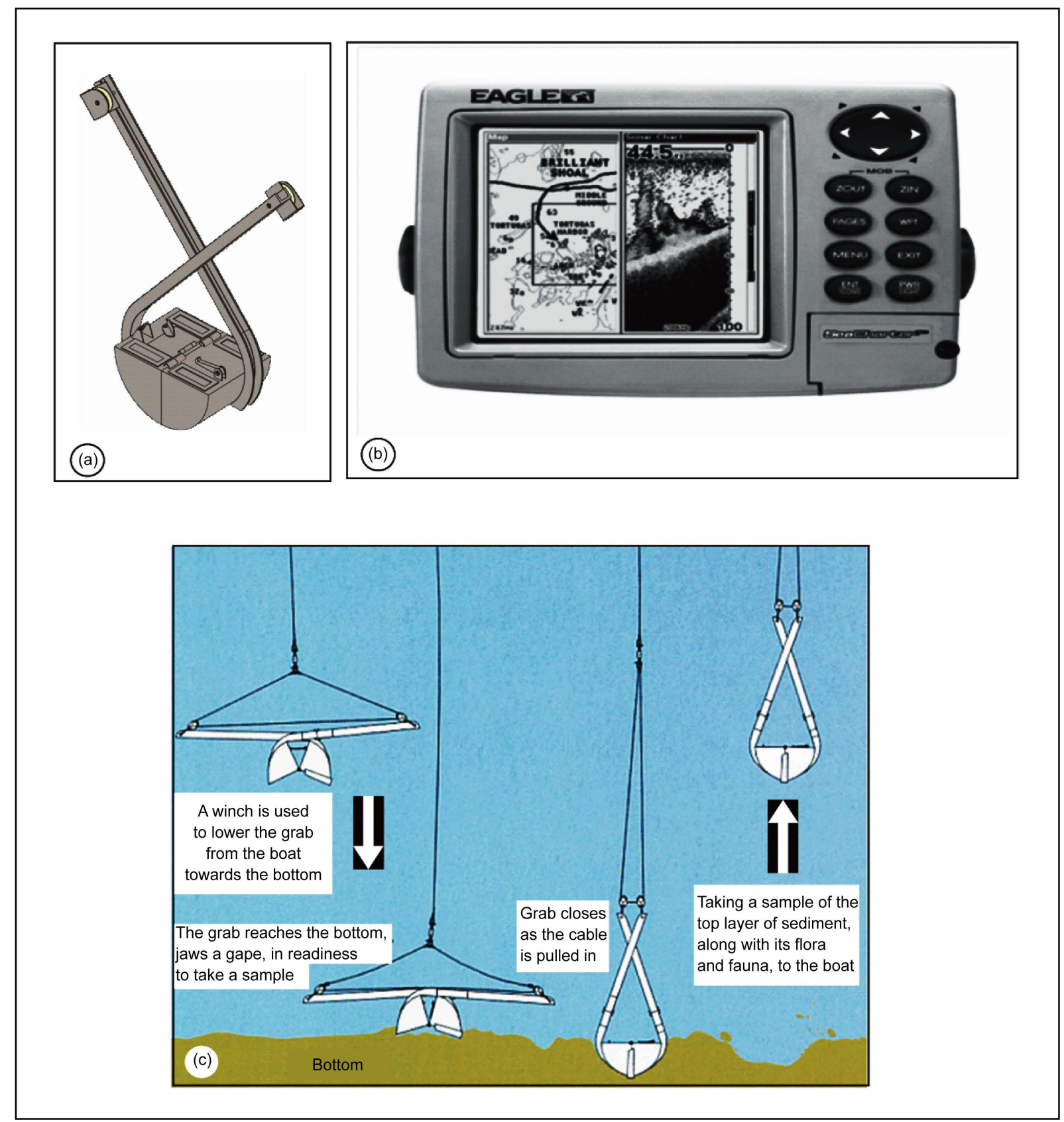

Figure 6. (a) A Van Veen Grab sampler. (b) Fish Elite 480 and Sea Charter 480DF echo sounder. (c) A steps of collecting samples by using van veer grab sampler.

smaller sub-reservoir covered by $(>50 \%-75 \%)$ of sandy silt (Figure $9(\mathrm{c})$ ). More than $30 \%$ to $45 \%$ of the clay sediments are deposited at the area where the Hizop stream enters the bigger sub-reservoir and near to the dam site in the smaller sub-reservoir too (Figure 9(c)). The abundance of clay and silt sediments in the Dukan Dam Reservoir might be due to low energy, quiet and calm depositional environment. Using Folk classification [18], it has been concluded that mud and silt are the main components of the deposited sediments at the bottom of the Dukan Dam reservoir (Figure 10). 


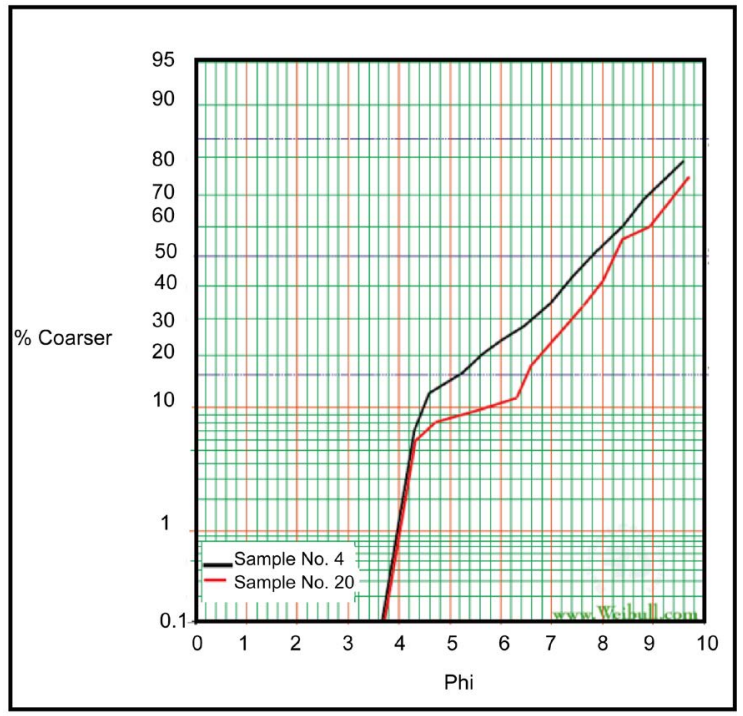

Figure 7. Grain size distribution of the bottom sediment in Dukan Reservoir.

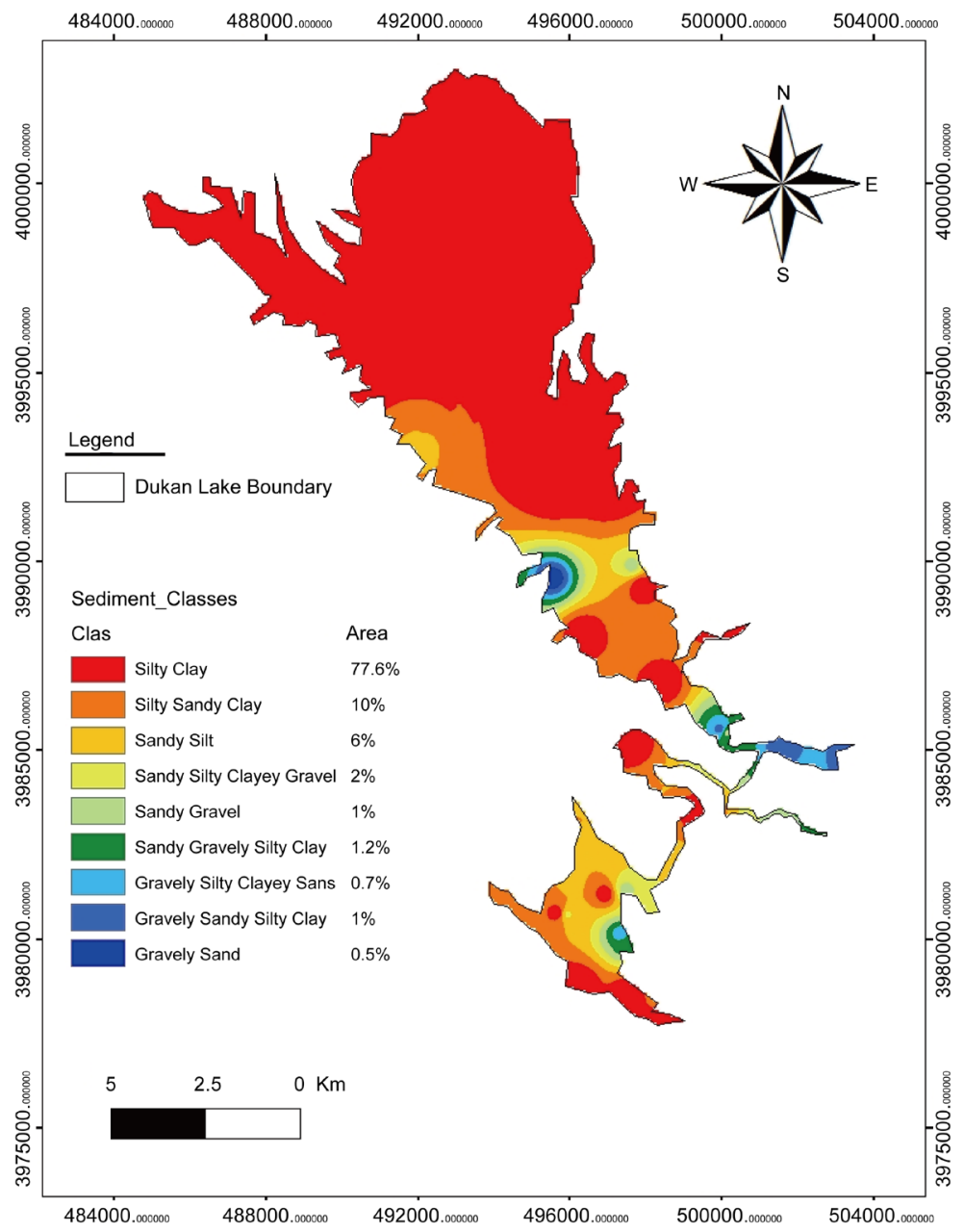

Figure 8. A map shows the different classes of the sediments with their surface distribution area percentages at the surface of the bottom of the Dukan Dam Reservoir. 


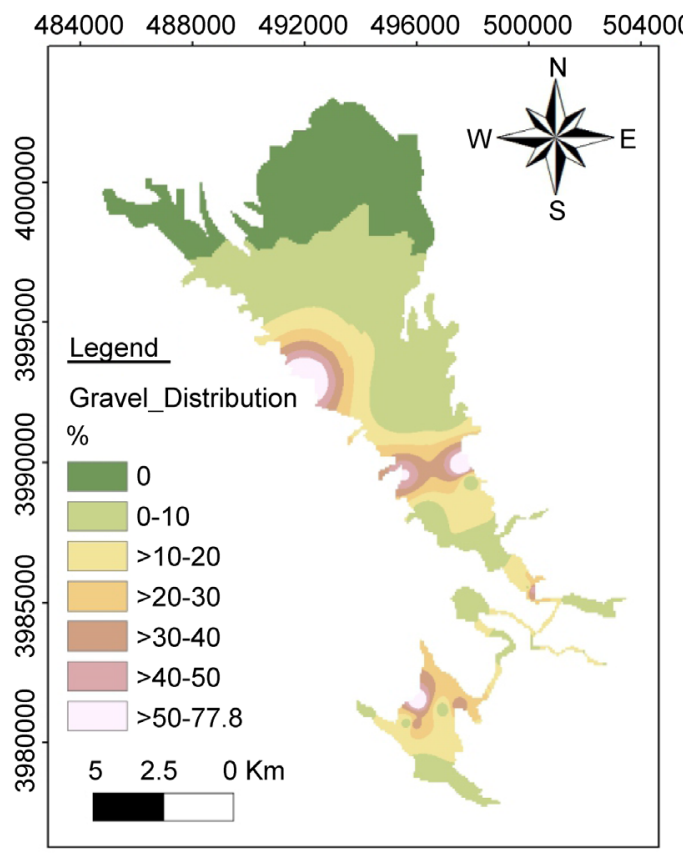

(a) Gravel distribution

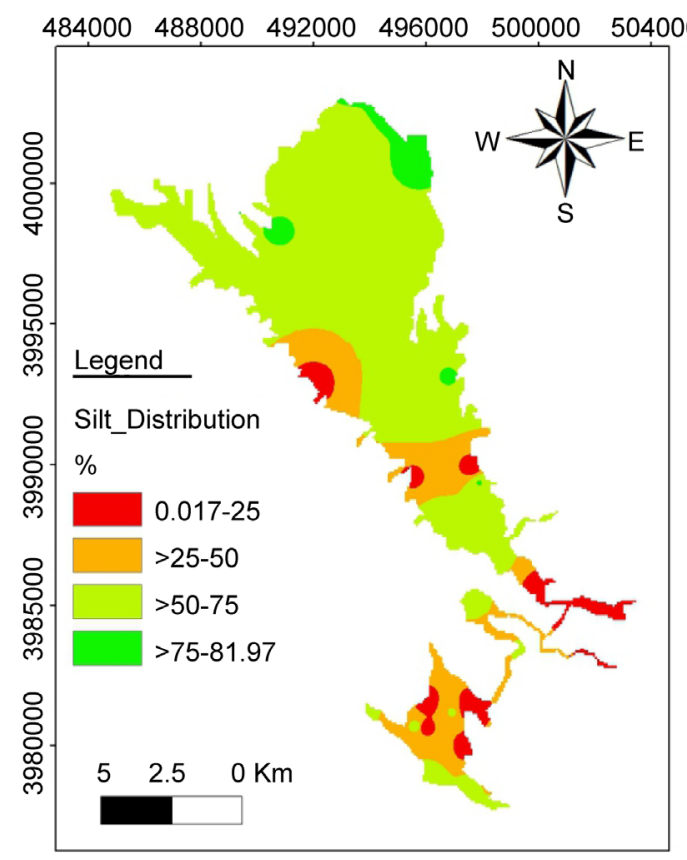

(c) Silt distribution

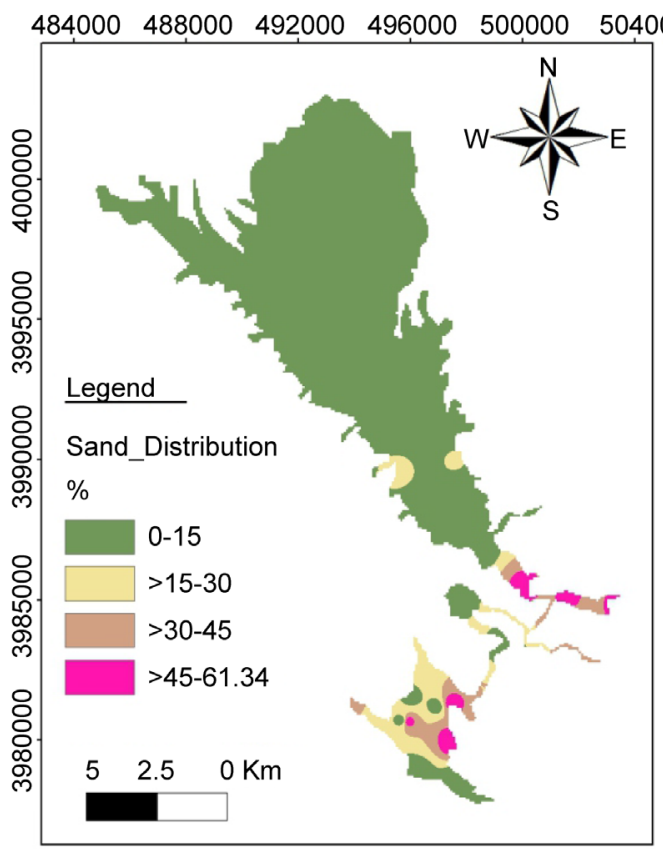

(b) Sand distribution

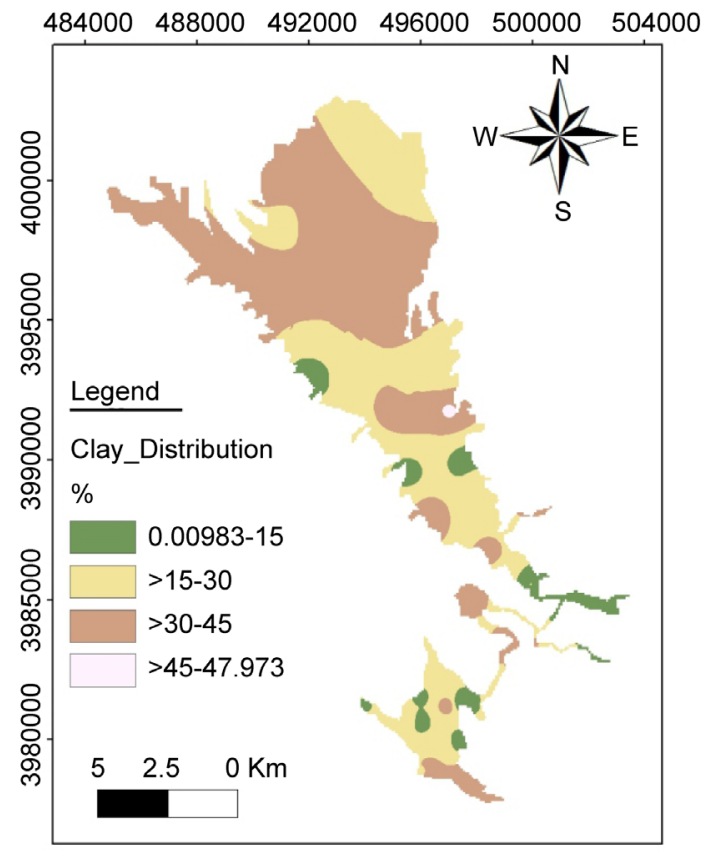

(d) Clay distribution

Figure 9. A maps of the Dukan Dam Reservoir show the surface distribution area percentages of the deposited (a) gravel sediments, (b) sand sediments, (c) silt sediments, and (d) clay sediments. 


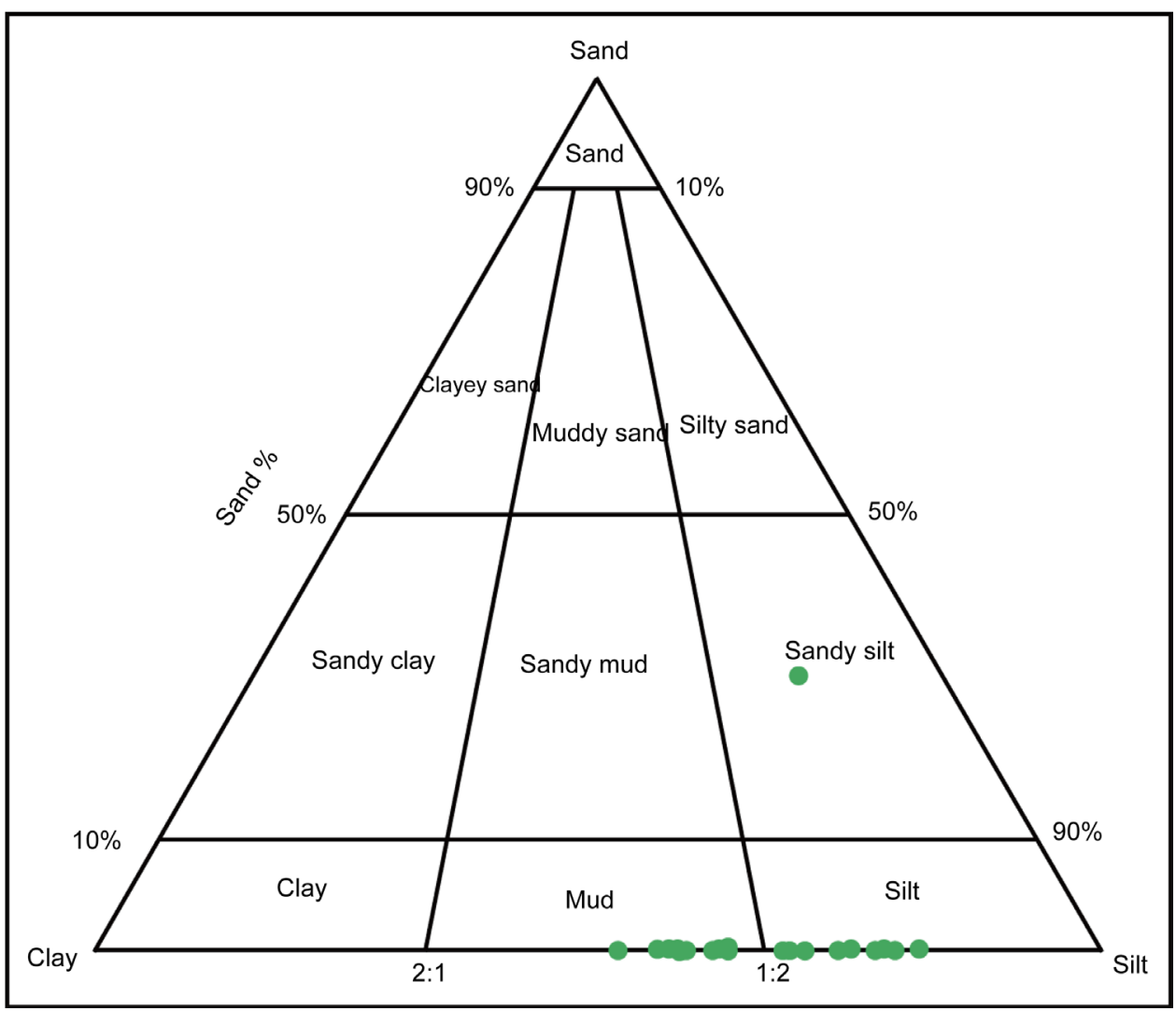

Figure 10. A Folk triangle classification (1954) shows the plotted bed sediment samples (green dots).

The calculated statistical parameters are used for describing the grain size distribution. Theses parameters include the average size (mean and median values), sorting or spread of the particle sizes around the average (standard deviation), symmetry or preferential spread to one side of the average (skewness) and the degree of concentration of the grains relative to the average (kurtosis). Depending on the calculated median and mean values of the sediment samples, it can be said that more than half $(64.5 \%-80.6 \%)$ of the sediments are fine-grained sediments except some patches of coarser sediments which appear in the lower and upper parts of the bigger and smaller sub-reservoirs (Figure 11(a) \& Figure 11(b)) which might be due to wave actions or water flow velocity change across the gorge between the two sub-reservoirs. It can be noticed that the majority of the bottom sediment covers the bed of the reservoir having a graphic mean between 6 to 9.79 phi (Figure 11(a)) and median diameter ranging between 0.0022 to 0.25 phi (Figure $11(\mathrm{~b})$ ).

It has been concluded from the standard deviation values of the sediments that (77.4\%) of the deposited sediments in the reservoir are very poorly sorted (VPS) and (19.4\%) are extremely poorly sorted (EPS), and the rest of the sediments are poorly sorted (PS) which forms only (3.2\%) of the total deposited sediments. The extremely poorly sorted sediments are distributed as an elongate patch trending NW-SE near to the entrance of the Hizop stream and also as a patch near to the eastern shore of the re- 


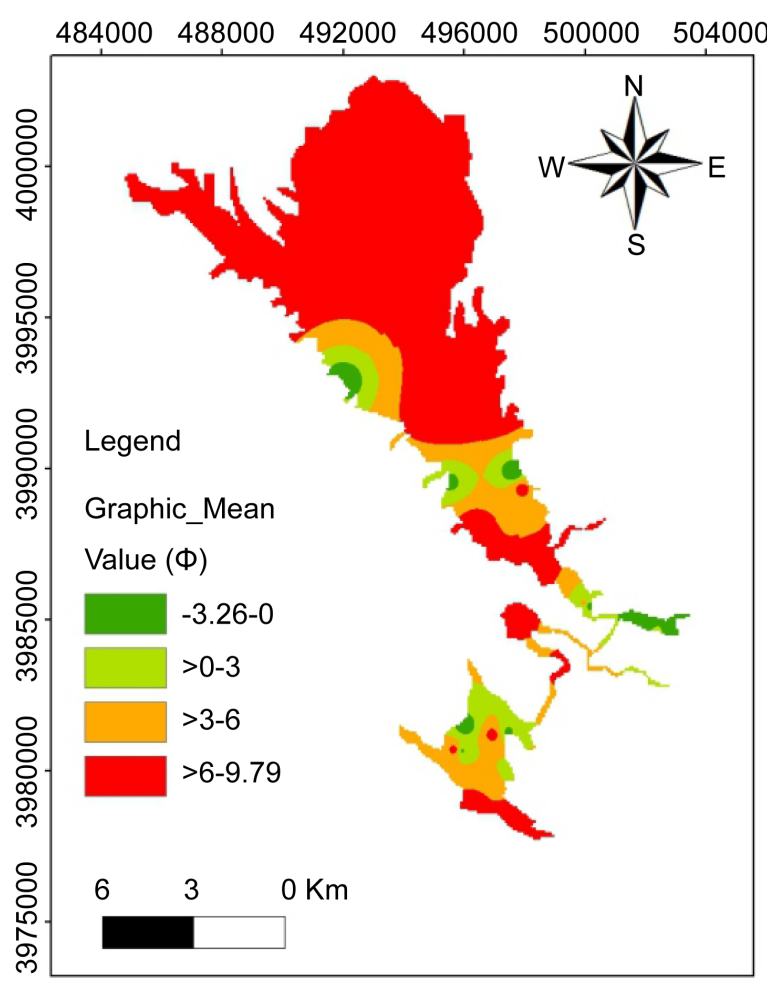

(a) Mean

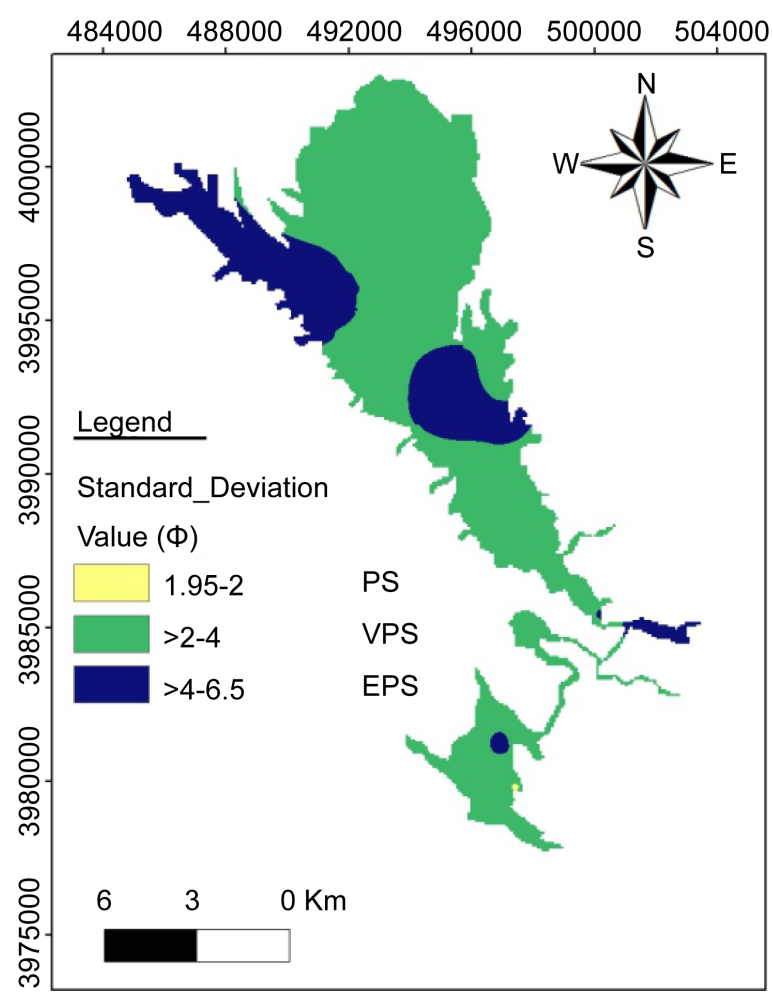

(c) Standard Deviation

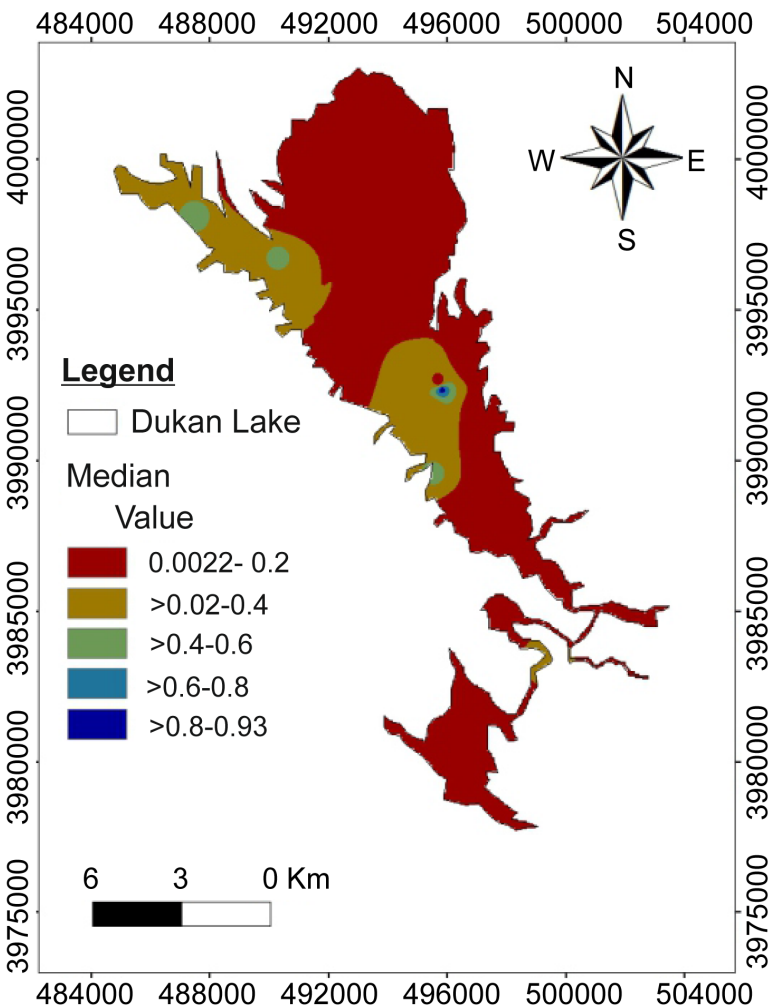

(b) Median

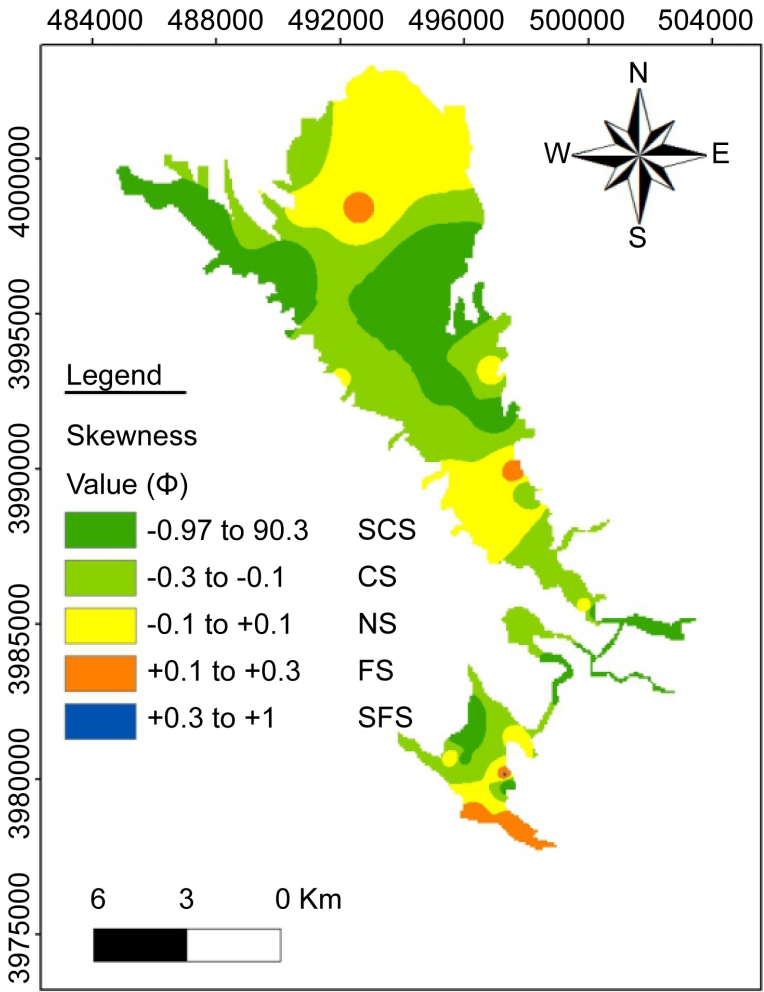

(d) Skewness 


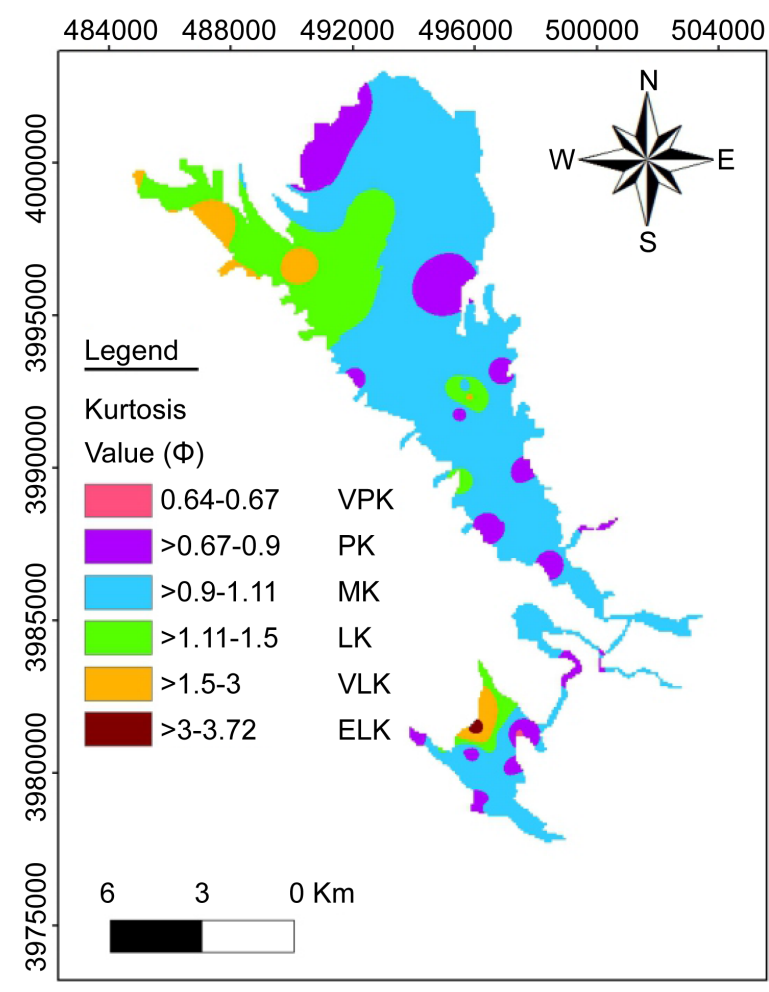

(e) Kurtosis

Figure 11. A maps showing the distribution of (a) the graphic mean, (b) median, (c) standard deviation (sorting), (d) skewness and (e) kurtosis fot the sediments deposited at the bottom of Dukan Dam Reservoir.

servoir (Figure 11(c)). This might be due to wave actions, variations in the water flow speed and rate and duration of deposition. The skewness statistical values indicate that strongly coarse skewed (SCS) and coarse skewed (CS) sediments represent (54.8\%) of the total deposited sediments on the reservoir bottom surface. These negatively skewed sediments (fine materials) are mostly distributed in the NW part of the reservoir near to the entrance of the Hizop stream and also in the central, lower parts of it (Figure 11(d)). The near symmetrical (NS) sediments are (29\%) of the total sediments and distributed in the upper most NE part of the reservoir near to the entrance of the Lesser Zab River and also in the lower part near to the dam site with a big patch in the triangle-shaped bigger reservoir. The calculated kurtosis statistical parameter shows that, among the deposited sediments on the Dukan Dam Reservoir bottom surface, the platykurtic sediments are the most dominant $(45.1 \%)$ but the extremely lepokurtic sediments are the least distributed (3.2\%). The mesokurtic sediments represent (32.2\%), whilst, each of the very platykurtic, lepokurtic and very lepokurtic sediments forms (6.5\%) of the total deposited sediments in the reservoir. The platykurtic sediments are distributed as patches near to the shore lines and the very lepokurtic and lepokurtic sediments are mostly seen in the NW part of the bigger triangle-shaped sub-reservoir near to the entrance of the Hizop stream to the reservoir and the northern part of the smaller irregular-shaped sub-reservoir (Figure 11(e)). The mesokurtic sediments are 
most dominant in the area where the Lesser Zab River enters the reservoir (Figure $11(\mathrm{e}))$.

\section{Conclusions}

Dukan Dam is one of the oldest dams in Iraq. It started operating in 1959. Its reservoir has a surface area that reaches 270 square kilometers and is composed of two sub-reservoirs. The relatively bigger reservoir is located in the north and has a triangular shape with a surface area approximately 250 square kilometers. The smaller sub reservoir is located down south where the dam exists and has irregular rectangular shape.

Thirty-two bottom sediment samples were collected from the bottom of the reservoir using Van Veen grab. Grain size distribution analyses indicated that bed of the reservoir was mainly composed of $15 \%$ gravel, $14 \%$ sand, $48 \%$ silt, and $23 \%$ clay, respectively. Mud and silt were the main components of the samples. The distribution of the sediment covering the bed was: $89.9 \%, 6 \%, 3 \%$ and $1.2 \%$ of clay, sandy silt, gravel and sand sediments respectively. The sediments are very fine grained, very poorly sorted, strongly coarse skewed and mesokurtic.

\section{References}

[1] Mooris, G.L. and Fan, J. (1998) Reservoir Sedimentation Handbook, Design and Management of Dams, Reservoirs, and Watersheds for Sustainable Use. McGraw-Hill Book Co., New York.

[2] Mamma, C.N. and Okafor, F.O. (2011) Siltation in Reservoirs. Nigerian Journal of Technology, 30, 85-90.

[3] Mahmood, K. (1987) Reservoir Sedimentation: Impact, Extent, Mitigation. World Bank Tech. Rep. 71, Washington DC.

[4] White, W.R. (2001) Evacuation of Sediment from Reservoirs. Thomas Telford, London. http://dx.doi.org/10.1680/eosfr.29538

[5] Folk, R.L. and Ward, W.C. (1957) Brazas River Bar-A Study in the Significance of GrainSize Parameters. Journal of Sedimentary Research, 27, 3-26.

[6] Friedman, G.M. (1979) Differences in Size Distributions of Populations of Particles among Sands of Various Origins. Sedimentology, 26, 859-862.

http://dx.doi.org/10.1111/j.1365-3091.1979.tb00979.x

[7] Bui, E.N., Mazullo, J. and Wilding, L.P. (1989) Using Quartz Grain Size and Shape Analysis to Distinguish between Aeolian and Fluvial Deposits in the Dallol Bosso of Niger (West Africa). Earth Surface Processes and Landforms, 14, 157-166. http://dx.doi.org/10.1002/esp.3290140206

[8] Blott, S.J. and Pye, K. (2001) Gradistat: A Grain Size Distribution and Statistics Package for the Analysis of Unconsolidated Sediments. Earth Surface Processes and Landforms, 26, 1237-1248. http://dx.doi.org/10.1002/esp.261

[9] Sissakian V.K., Abdul Ahad, A.D., Al-Ansari, N.A., Hassan, R. and Knutsson, S. (2016) The Regional Geology of Dukan Area, NE Iraq. Journal of Earth Sciences and Geotechnical Engineering, 6, 35-63

[10] Lawa, F.A., Koyi, H. and Ibrahim, A. (2013) Tectono-Stratigraphic Evolution of the NW Segment of the Zagros Fold-Thrust Belt, Kurdistan, NE Iraq. Journal of Petroleum Geology, 36, 75-96. http://dx.doi.org/10.1111/jpg.12543 
[11] Jassim, S.Z. and Buday, T. (2006) Tectonic Framework. In: Jassim, S.Z. and Goff, J.C., Eds., Geology of Iraq, Publication of Dolin, Prague and Moravian Museum, Brno, 341 p.

[12] Al-Hakari, S.H. (2011) Geometric Analysis and Structural Evolution of NW Sulaimani Area, Kurdistan Region NE Iraq. Unpub. PhD Thesis, University of Sulaimani, Kurdistan Region.

[13] Buday, T. and Jassim, S. (1987) The Regional Geology of Iraq: Tectonics, Magmatism, and Metamorphism. In: Kassab, I.I. and Abbas, M.J., Eds., Geology of Iraq, Geologic Survey, Baghdad, $445 \mathrm{p}$

[14] Karim, K.H. and Taha, Z.A. (2012) Origin of Conglomeratic Limestone "Dukan Conglomeraye”, in Dukan Area, Kurdistan Region, NE Iraq. Iraqi Bulletin of Geology and Mining, 8, $15-24$.

[15] Sissakian, V.K. (2000) Geological Map of Iraq, Scale 1:1000000. 3rd Edition, Iraq Geological Survey Publications, Baghdad.

[16] Taha, Z.A. and Karim, K.H. (2009) New Ideas about Gulneri Shale Formation (Early Turonian) in Dukan Area, Kurdistan Region, NE Iraq. Iraqi Bulletin of Geology and Mining, 5, 29-39.

[17] Shepard, F.P. (1954) Nomenclature Based on Sand-Silt-Clay Ratios. Journal of Sedimentary Research, 24, 151-158.

[18] Folk, R.L. (1954) The Distinction between Grain Size and Mineral Composition in Sedimentary-Rock Nomenclature. Journal of Geology, 62, 344-359.

\section{Submit or recommend next manuscript to SCIRP and we will provide best service for you:}

Accepting pre-submission inquiries through Email, Facebook, LinkedIn, Twitter, etc. A wide selection of journals (inclusive of 9 subjects, more than 200 journals)

Providing 24-hour high-quality service

User-friendly online submission system

Fair and swift peer-review system

Efficient typesetting and proofreading procedure

Display of the result of downloads and visits, as well as the number of cited articles

Maximum dissemination of your research work

Submit your manuscript at: http://papersubmission.scirp.org/ 